
\title{
25 Research Soure \\ In Vitro Anti Sickling Activity of HyphaeneThebaica Fruits Extract on Sickle Cell
}

\section{Toga Abdalazim Fadlalla \\ Alzaiem Alazhari University \\ Nusiba Abdullah Yousif \\ Alzaiem Alazhari University Faculty of Medicine}

\section{Rayan Hamid Omer}

Alzaiem Alazhari University

\section{Mohamed Mobarak Elbasheir}

Alzaiem Alazhari University

\section{WalaEldin Osman Elradi}

Alzaiem Alazhari University

Elharam Ibrahim Abdallah ( $\nabla$ hoyam.ibrahim@yahoo.com )

Alzaiem Alazhari University https://orcid.org/0000-0001-5722-1048

\section{Research}

Keywords: In vitro, Anti-sickling activity, HaphaeneThebaica, Percentage of unsickled red blood cells, Sickle cell disease

Posted Date: June 30th, 2020

DOI: https://doi.org/10.21203/rs.3.rs-32120/v1

License: (c) (i) This work is licensed under a Creative Commons Attribution 4.0 International License.

Read Full License 


\section{Abstract}

Background: Traditional medicine had been used alongside synthetic pharmaceutical products to enhance health management. Due to the high mortality rate of sickle cell patients, previous studies have been indicated that some medicinal plants have shown an anti-sickling activity, which indicates a new therapeutic way to manage people who are affected by these disorders. The current study aimed to assess in vitro-anti-sickling activity of Hyphaene thebaica (H thebaica) (Doum) fruit.

Materials and methods: Blood samples used in the evaluation of the anti-sickling activity of Hyphaene Thebaica Fruits extract in this study was taken from patients known to had Sickle cell disease (HB -SS ) attending the Sickle Cell Clinic in Khartoum state. Emmel test was used to assess anti-sickling activity of this plant.

Result: A significant increase in the percentage of unsickled Red blood cells with p-value $0.05>$ was observed after incubation of RBCs with $2 \%$ sodium metabisulfite in the presence of three different concentration $(1000,500$ and 250$) \mu \mathrm{g} / \mathrm{ml}$ of Hyphened thebaica for two type of extraction (aqueous and methanol) extract.

Conclusion: This study approved that H.thebaica (Doum ) fruit extract had a strong anti- sickling activity ; it could be used for management of sickle cell disease.

\section{Background}

Sickle cell disease (SCD) is a genetic disorders cause by single point mutation in the sixth codon of the beta globin chain which affect the amino acid constituent of goblin chain leading to change in the hemoglobin affinity toward oxygen and also changes the hemoglobin solubility under low oxygen pressure. This mutation and their consequences of symptoms are the reasons of the high mortality rate in SCD , especially in children of developing country such as Sudan where the chemotherapy is choice of the good income parents and alongside the adverse effect of this medications so there are emerging needs for traditional drugs which are consider safe treatments with reasonable price.[1,2]

Some of medicinal plants are thought to be responsible for observed antisickling action for their high contain of phenolic compounds and antioxidant nutrients. Antioxidants (scavengers of free radicals) are thought to be major components of these antisickling action thus different antisickling agents have different degrees of effect according to amount of antioxidant. [3] So that the higher antioxidant property of an antisickling agent enables it to reduce oxidative stress that contributes to sickle cell crisis. Hyphaene thebaica common name is African doum palm it is a type of desert palm tree with edible oval fruit which belongs to the family Arecaceae. Doum palm is native to the northern half of Africa; it tends to grow along the Nile River in Egypt and Sudan in the areas which contain ground water. The extracts of Hyphaene thebaica was used in treatment of hypertension, bilharzias and as a haematinic agent. doum fruit extracts contain high amount of flavonoids, phenols used as antioxidant and antibacterial activities which can alleviate the adverse effects of oxidative stress.[4] 
phytochemical components show medicinal values of these plants, which produce definite and various physiological action on human body. Some of the most important of these components are flavonoids, alkaloids and phenolic compounds [5].

Phytochemicals are extensively present at different level in many medicinal plants and used in herbal medicines to treat different ailment such as cough, diabetes, hypertension, cancer, and various types of bacterial infections. It is also

used to treat sickle cell crises associated morbidities among the less privileged classes of the society [6].

\section{Doum Palm (Hyphaene thebaica)}

Hyphaene thebaica its common name is African doum palm it is a type of desert palm tree with edible oval fruit which belongs to the family Arecaceae. The doum palm is native to the northern half of Africa. It grows in the west from Mauritania and Senegal, and east to Egypt, Kenya and Tanzania.

It tends to grow along the Nile River in Egypt and Sudan in the areas which contain ground water. The various extracts of Hyphaene thebaica used in the treatment of hypertension, bilharzias and as a haematinic agent. Several studies have recorded that doum fruit extracts contain high amount of flavonoids, phenols used as antioxidant and antibacterial activities which can alleviate the adverse effects of oxidative stress [7].

\section{Chemical composition of Doum fruit}

Doum fruit has a high-quality protein varied between 2.86 and $5.01 \%$, high proportion of lysine and cysteine of crude protein varied between $4.09-4.16 \%$ and $0.2-1.62 \%$, respectively, the limited amino acid threonine, crude fat varied between 1.2 and $8.4 \%$, crude fiber varied between 52.26 and $66.5 \%$, the most important carbohydrates component was mannose varied between 13 and $75.9 \%$, also the presence of calcium, magnesium, potassium, iron sodium and negligible amount of nickel, cobalt and molybdenum. Phytochemical compounds of doum fruit such as tannins, saponin, steroids, glycosides, flavonoid, terpenes and terpinoids were found at low and moderate concentrations [7].

\section{Chemical structure of doum fruit phenolic compounds}

Different total soluble phenols values in doum were published in different studies; it ranged from 45.08 to $64.90 \mathrm{mg} \mathrm{GAE} / \mathrm{g} \mathrm{DW}$. While it recorded the highest values in pitted doum fruit extracts varied from 116.26 to $139.48 \mathrm{mg} \mathrm{GAE} / \mathrm{g}$ DW . The bioactive potential of fruits and vegetables attributed to their high content of polyphenols [28 The most abundant phenolic compounds recorded in doum were metoxicinnamic acid, sinapic acids (hydroxycinnamic acids), chlorogenic 
acid, catechin, p-hydroxybenzoic acid, vanillic acids, 3,4 di hydroxycinnamic acid, caffeic acid, 2-hydroxycinnamic acid, Epicatechinand cinnamic acid, respectively Doum pulps exhibited higher caffeic acid contents in comparison to the domestic fruits. The highest four concentrations of phenolic compounds in doum fruit aqueous extracts were found to be $3-\mathrm{OH}$ tyrosol, E-vanillic acid, catechin and chlorogenic acid, while the lowest were of alpha-coumaric acid, cinnamic acid, p-coumaric acid and coumarin [7].

\section{Total flavonoids content and compounds of Doum fruits}

The total flavonoids content in different extracts of doum fruit extracts varied widely ranging from 24.04 to $47.17 \mathrm{mg}$ rutin/g DW. Similar results found that the content of flavonoids $(\mathrm{mg} / \mathrm{g})$ of fruits of $H$. thebaica, in the quercetin equivalent was $46.28 \mathrm{mg} / \mathrm{g}$ DW . HPLC analysis of aqueous doum fruit extracts showed 11 flavonoid compounds. The highest concentrations were quercetin, hesperetin, naringin and rutin compounds. Five flavone glycosides were isolated 4

and identified from doum fruits namely, luteolin 7-0-ßglucuronoide, apigenin 7$O-\beta$-glucuronoide, luteolin $O-\beta$-glycoside, luteolin 7-O-rutinoside.[7]

\section{Materials And Methods}

This was experimental done in Khartoum state from September 2019 to January 2020. The study populations were ten sickle cell anemia samples obtained from diagnosed sickle cell disease patients (HBSS).

\section{Inclusion and exclusion criteria}

Samples had been collected from sickle anemia patient, including both genders in different age. Patients already diagnosed with other disorder and hereditary hemoglobinopathy was excluded from the study.

\section{Preparation of the aqueous extract of doum fruits}

$40 \mathrm{~g}$ of the doum fruits was extracted by soaking in $200 \mathrm{ml}$ hot distilled water for about four hours with continuous steering. Then after cooled, extract was filtered using filter paper and stored till used. Concentration was calculated by dried $2 \mathrm{ml}$ of the extract in a Petri dish using water [5].as followed:

(Weight of dish with extract - empty weight) X $100 / 2$

\section{Preparation of methanol extract}

$100 \mathrm{~g}$ of the plant sample was coarsely powdered using mortar and pestle. Then soaked in absolute methanol. Extraction carried out for three days with daily filtration and evaporation the solvent under reduced pressure using rotary evaporator apparatus. Sample extract was allowed to air in evaporating 
dish till complete dryness and the yield $9.92 \%$ were calculated[5] .as follows: Weight of extract obtained / weight of plant sample X 100 .

\section{Methodology}

\section{Washing of RBCs}

About $4 \mathrm{ml}$ Ethylene diamine tetra acetate (EDTA) blood samples had been obtained from patients then centrifuged at $3000 \mathrm{rpm}$ for 10 minutes to remove the plasma. The resulting packed erythrocytes had been washed 3 times with $1 \mathrm{ml}$ sterile normal saline per $5 \mathrm{ml}$ of blood. The samples had been centrifuged each time to remove the supernatant.

\section{Procedure for anti-sickling activity evaluation}

Three diluted solutions in normal saline had been prepared from the stock solution of plant extract as follows $(250,500$, and $1000 \mu \mathrm{g} / \mathrm{ml})$. Emmel test: Washed erythrocyte had been mixed with an equivalent volume of $2 \%$ sodium metabisulfite (Na2O5S2). $10 \mu \mathrm{l}$ from the above mixture had been spotted on a microscope slide then $10 \mu \mathrm{l}$ from the plant extracts had been added and mixed with the blood mixture. $10 \mu \mathrm{l}$ normal saline had been added to one of the slides instead of the plant extract which served as control; all the slides had been covered with a cover slip. Paraffin had been applied to seal the edges of the cover completely to exclude air (hypoxia), and then, slides had been incubated for one hour minutes. Each slide had been examined under oil immersion light microscope, and red blood cells (RBCs) had been counted in five different fields of view across the slide. The numbers of both sickled and unsickled blood cells had been determined, and the percentage of unsickled cells had been calculated using the formula: $\{(\%)$ unsickling $=$ Number of unsickling cells $\times 100 /$ total red blood cells $\}$.

\section{Statistical analysis}

Data had been reported as mean \pm standard deviation (S.D), independent $T$ test had been used to compare between mean value of the control and different concentration of extracts and also to calculated p-value. P-values less than 0.05 were considered significant.

\section{Results}

The mean \% of unsickel cells when Incubated with $H$. Thebica aqueous extract in different concentrations were ) $96.6 \pm 3.7,95.3 \pm 5.2$ and $96.3 \pm 4.9$ ) Respectively when compared with mean $\%$ of control (59.7 \pm $31.3)$, The results were statistically significant with $p$-value $(0.005,0.006$ and 0.005$)$ respectively. There were no statistical significant different between aqueous extractions of different concentration $(1000$, 500 and $250 \mu \mathrm{g} / \mathrm{ml})$ p-value were $(0.52,0.89$ and 0.61$)$ respectively.

Mean \% of unsickle cells when incubated with $H$. Thebica methanol extract in different concentrations $(1000,500$ and $250 \mu \mathrm{g} / \mathrm{ml}$ ) were ) $97.9 \pm 2.8,98.1 \pm 2$ and $96.4 \pm 3.8$ (respectively, when compared with 
mean $\%$ of control $(59.7 \pm 31.3)$, results were statistically significant with $p$-value $(0.004,0.004$ and 0.005$)$ respectively.

There was no statistically significant difference when compared the three different concentration of methanol extraction of Doum $(1000,500$ and $250 \mu \mathrm{g} / \mathrm{ml})$ p-value were $(0.94,0.27$ and 0.24$)$ respectively . Also there was no statistical significant difference observed when compared the mean $\%$ of un-sickle cells of the three aqueous extraction concentration versus the three methanolic extraction concentration, for all p-value $<0.05$

\section{Discussion}

This study demonstrates that Anti-sickling activity of aqueous and methanol extract of Doum fruit; the effect of plant crude extracts in different concentration $(100,500$ and $250 \mu \mathrm{g} / \mathrm{ml})$ on sickle cell after the incubation for one hour, the results were highly significant all p-values $0.05>$ this result in concordance with study done by HS El-Beltagi, Mohamed HI, etal (2018) [4]; demonstrate that doum Fruit extraction had bioactive potential attributed to their high content of antioxidant (phenols compound an flavonoids) ; antioxidant activity had direct proportion to anti sickling activity[8,9].

Multiple Comparisons of mean of \% of un sickle cells in aqueous extraction in different concentrations confirmed that no statistically different between Doum extraction of different concentrations. The results were disagreed with study done by Mohamed AA, etal (2010) [9]; they found that the aqueous doum extract exhibited antioxidant activity increased with the increased of extract concentration in this study all concentration had similar anti sickling activity with no statistical significant differences this may be due to different in experiment variables .

Time course for antisickling activity of the aqueous and methanol extract of Doum fruit ( 60 minute incubation) carried out on blood samples of sickle cell disease revealed significant effect on $\%$ of un sickle cell when compared with control. The majority of antioxidants, both natural and synthetic, are phenolic compounds $[10,11]$. In this study Doum extract had strong antisickling activity, could be due to the high content of antioxidant.

According our information, no previous study was done to determine the activity of Doum extract on sickle cells.

\section{Conclusion}

This study approved that $H$.thebaica (Doum) fruit extract had a strong anti sickling activity so it could be used for management of sickle cell disease due to its great amount of antisicking agent such as phenol compound and flavonoid and also it is consider cheap and one of the abundant fruits in Africa .Further in vivo studies are recommended to evaluate the effect and to determine the mode of action of this plant.

\section{Abbreviations}


HB-SS: Homozygous sickle cell hemoglobin;

SCD: Sickle cell disease;

EDTA: Ethylene diamine Tetra-acetate;

Na205S2: Sodium metabisulfite;

RBCs: Red blood cells;

SD: Standard deviation;

Hthebaica: Hyphaene thebaica.

\section{Declarations}

\section{Acknowledgment}

Deep appreciation to hematology staff of Alzaiem Alazhari University for their guidance at each step in this work also Especial thanks to sickle cell disease patients who donate their samples to accomplish this study.

\section{Authors'contributions}

All authors was contributing in writing and revising of paper, Toga Abdalazim was the main experimenter for the work, Nusiba Abdullah, Rayan Hamid and WalaEldin Elradi were the co-workers for the experiment, Mohammed Mobarak and Elharam Ibrahim were the main writers and reviewers of this research work.

\section{Funding}

Not applicable

\section{Availability of data and materials}

Data will be available for public without any restriction, while materials will be available under request from corresponding author.

\section{Ethics approval and consent to participate}

This study had been approved by the faculty of medical laboratory sciences, Al-zaiem Al-azhary University. The purpose of this study had been clarified and discussed with the patients and their relatives. Samples had been taken after informed consent from hospital and verbal consent from patients.

\section{Consent for publication}


All authors consent for publication.

\section{Competing interest}

Not applicable

\section{Authers details}

${ }^{1}$ Department of Haematology\&Immunohaematology, Faculty of Medical Laboratory Sciences, Alzaiem Alazhari University, Khartoum State, Sudan.

2 Department of Parasitology \& Medical Entomology, Faculty of Medical Laboratory Sciences, Alzaiem Alazhari University, Khartoum State, Sudan.

\section{References}

1.Hoareau L, DaSilva EJ. Medicinal plants: a re-emerging health aid.

Electronic Journal of biotechnology. 1999 Aug;2(2):3-4.

2. Dash BP, Archana Y, Satapathy N, Naik SK. Search for antisickling agents from plants. Pharmacognosy reviews. 2013 Jan;7(13):53.

3. Pauline N, Cabral BN, Anatole PC, Jocelyne AM, Bruno M, Jeanne NY. The in vitro antisickling and antioxidant effects of aqueous extracts Zanthoxyllum heitzii on sickle cell disorder. BMC Complementary and Alternative Medicine. 2013 Dec;13(1):162.

4. Kato GJ, Piel FB, Reid CD, Gaston MH, Ohene-Frempong K, Krishnamurti L, et al. Sickle cell disease. Nature Reviews Disease Primers. 2018;4:18010.

5. Rab MA, van Oirschot BA, Bos J, Kanne CK, Sheehan VA, van Beers EJ, et al. Characterization of Sickling During Controlled Automated Deoxygenation with Oxygen Gradient Ektacytometry. JoVE (Journal of Visualized Experiments). 2019(153):e60213

6. .Brugnara C. Sickle cell dehydration: Pathophysiology and therapeutic applications. Clinical hemorheology and microcirculation. 2018;68(23):187-204 .

7. El-Beltagi HS, Mohamed HI, Yousef HN, Fawzi EM. Biological Activities of the Doum Palm (Hyphaene thebaica L.) Extract and Its Bioactive Components. Antioxidants in Foods and Its Applications. 2018 Apr 3:49.

8. L. Tatum and C. K. Chow, "Antioxidant status and susceptibility of sickle erythrocytes to oxidative and osmotic stress," Free Radical Research, vol. 25, no. 2, pp. 133-139, 1996. 
9. Imaga NA. Phytomedicines and nutraceuticals: alternative therapeutics for sickle cell anemia. The scientific world journal. 2013;2013.

10. Mohamed AA, Khalil AA, El-Beltagi HES. Antioxidant and antimicrobial properties of kaff maryam Anastatica hierochuntica and doum palm Hyphaene thebaica. Grasas y Aceites.2010;61:67-75.

11. M. J. Brown, H. E. David, and C. Hunt, "Comparison of the antioxidant properties of supercritical fluid extracts of herbs and the confirmation of Pinocembrin as a principal antioxidant of Mexican Oregano (Lippa gravolens)," Electronic Journal of Environmental, Agricultural and Food Chemistry, vol. 3, pp. 102-107, 2006.

\section{Tables}

Table1: Multiple Comparisons of mean of $\%$ of un sickle cells in aqueous extraction and control

\begin{tabular}{|lllll|}
\hline (I) & (II) & Mean (I) & Mean (II) & P. value \\
\hline Control & A $1000 \mu \mathrm{g} / \mathrm{ml}$ & $59.7 \pm 31.3$ & $96.6 \pm 3.7$ & 0.005 \\
\cline { 2 - 2 } \cline { 5 - 5 } & & & $95.3 \pm 5.2$ & 0.006 \\
\cline { 2 - 2 } & A $500 \mu \mathrm{g} / \mathrm{ml}$ & & $96.3 \pm 4.9$ & 0.005 \\
\hline
\end{tabular}

A; Aqueous extraction , $p$-value $>0.05$ : significant difference

Table 2: Multiple Comparisons of mean of \% of un sickle cells in aqueous extraction

\begin{tabular}{|lllll|}
\hline (I) & (II) & Mean (I) & Mean (II) & P. value \\
\hline A $1000 \mu \mathrm{g} / \mathrm{ml}$ & A $500 \mu \mathrm{g} / \mathrm{ml}$ & $96.6 \pm 3.7$ & $95.3 \pm 5.2$ & 0.520 \\
\cline { 2 - 3 } & A $250 \mu \mathrm{g} / \mathrm{ml}$ & & $96.3 \pm 4.9$ & 0.892 \\
\cline { 1 - 2 } A $500 \mu \mathrm{g} / \mathrm{ml}$ & A $250 \mu \mathrm{g} / \mathrm{ml}$ & $95.3 \pm 5.2$ & $96.3 \pm 4.9$ & 0.611 \\
\hline
\end{tabular}

A ; Aqueous extraction , $p$-value $>0.05$ : significant difference 
Table 3: Multiple Comparisons of mean of $\%$ of un sickle cells in methanolicextraction and control

\begin{tabular}{|c|c|c|c|c|}
\hline (I) & (II) & Mean (I) & Mean (II) & P. value \\
\hline \multirow[t]{3}{*}{ Control } & $\mathrm{M} 1000 \mu \mathrm{g} / \mathrm{ml}$ & $59.7 \pm 31.3$ & $97.9 \pm 2.8$ & 0.004 \\
\hline & 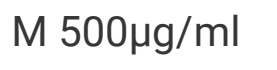 & & $98.1 \pm 2.4$ & 0.004 \\
\hline & $\mathrm{M} 250 \mu \mathrm{g} / \mathrm{ml}$ & & $96.4 \pm 3.8$ & 0.005 \\
\hline
\end{tabular}

M; Methanolic extraction, $p$-value $>0.05$ : significant difference

Table 4: Multiple Comparisons of mean of \% of un sickle cells in methanolicextraction of Doum

\begin{tabular}{|lllll|}
\hline (I) & (II) & Mean (I) & Mean (II) & P. value \\
\hline $\mathrm{M} 1000 \mu \mathrm{g} / \mathrm{ml}$ & $\mathrm{M} 500 \mu \mathrm{g} / \mathrm{ml}$ & $97.9 \pm 2.8$ & $98.1 \pm 2.4$ & 0.937 \\
\cline { 2 - 3 } & $\mathrm{M} 250 \mu \mathrm{g} / \mathrm{ml}$ & & $96.4 \pm 3.8$ & 0.272 \\
\hline $\mathrm{M} 500 \mu \mathrm{g} / \mathrm{ml}$ & $\mathrm{M} 250 \mu \mathrm{g} / \mathrm{ml}$ & $98.1 \pm 2.4$ & $96.4 \pm 3.8$ & 0.241 \\
\hline
\end{tabular}

M; Methanolic extraction, $p$-value $>0.05$ : significant difference 
Table 5: Multiple Comparisons of mean of \% of un sickle cells in aqueous and methanolic extraction

\begin{tabular}{|c|c|c|c|c|}
\hline$(I)$ & (II) & Mean (I) & Mean (II) & P. value \\
\hline \multirow[t]{3}{*}{ A $1000 \mu \mathrm{g} / \mathrm{ml}$} & $\mathrm{M} 1000 \mu \mathrm{g} / \mathrm{ml}$ & \multirow[t]{3}{*}{$96.6 \pm 3.7$} & $97.9 \pm 2.8$ & 0.809 \\
\hline & 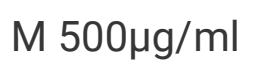 & & $98.1 \pm 2.4$ & 0.794 \\
\hline & 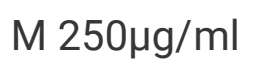 & & $96.4 \pm 3.8$ & 0.974 \\
\hline \multirow[t]{3}{*}{ A 500} & $\mathrm{M} 1000 \mu \mathrm{g} / \mathrm{ml}$ & \multirow[t]{3}{*}{$95.3 \pm 5.2$} & $97.9 \pm 2.8$ & 0.628 \\
\hline & 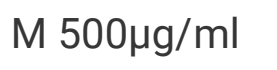 & & $98.1 \pm 2.4$ & 0.615 \\
\hline & 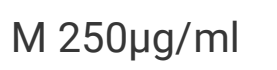 & & $96.4 \pm 3.8$ & 0.833 \\
\hline \multirow[t]{3}{*}{ A $250 \mu \mathrm{g} / \mathrm{ml}$} & $\mathrm{M} 1000 \mu \mathrm{g} / \mathrm{ml}$ & \multirow[t]{3}{*}{$96.3 \pm 4.9$} & $97.9 \pm 2.8$ & 0.770 \\
\hline & 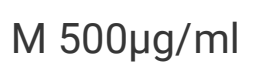 & & $98.1 \pm 2.4$ & 0.755 \\
\hline & $\mathrm{M} 250 \mu \mathrm{g} / \mathrm{ml}$ & & $96.4 \pm 3.8$ & 0.985 \\
\hline
\end{tabular}

A; Aqueous extraction , M; Methanol extraction, $p$-value $>0.05$ : significant difference Figures 


\begin{tabular}{|l|}
\hline Control \\
\hline
\end{tabular}

Test $(1000 \mathrm{mg} / \mathrm{ml})$ aqueous extract

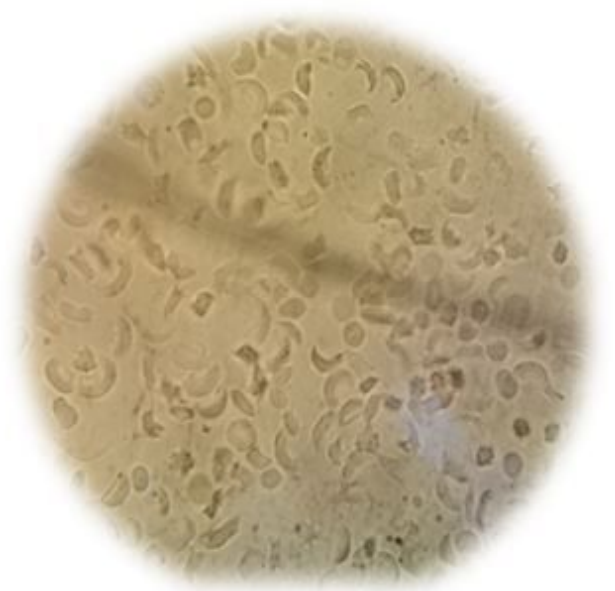

\section{Figure 1}

un sickle cells in control and $1000 \mu \mathrm{g} / \mathrm{ml}$ aqueous extraction 